\title{
The Relationship between Job Motivation Dimensions and Nurses' Subjective Well-being through the Mediating Role of Energy at Workplace
}

\author{
Noori Kaabomeir ${ }^{1}$, Parisa Hasanalipour ${ }^{2}$, Seyed Hashem Mousavi ${ }^{3}$
}

\begin{abstract}
Background \& Aims: Nurses are the largest group of professionals among health care workers who play a significant role in the community health system. Nurses work in environments where the life and death of patients are the most important issues, so their health and well-being become important and having a happy and positive spirit can help them improve their health and that of their patients. Organizations are also increasingly aware of the importance of their employees' well-being in striving to gain sustainable competitive advantages. Over the past decade, the concept of subjective well-being (SWB) has become a popular research topic, and many researchers have examined its implications at the organizational, group, and individual levels in the workplace. Subjective well-being helps organizations to effectively engage their employees at work in an attempt to achieve a sustainable competitive advantage. Sustaining employees' subjective well-being is a difficult task. Therefore, the present study aimed to investigate the relationship between intrinsic motivation, extrinsic motivation, and amotivation with nurses' subjective well-being through the mediating role of energy in the workplace.

Materials \& Methods: This correlational study was conducted in 2020 following structural equation modeling (SEM). The statistical population of this study included all nurses at Baqai Hospital in Ahvaz. The total number of nurses in this hospital was about 200. According to the population size, all nurses were selected as the sample through census method. Among the collected questionnaires, 193 questionnaires were analyzed. The instruments used in this study were: Multidimensional Work Motivation Scale (MWMS) developed by Gagné et al., Energy Scale (ES) developed by Atwater and Carmeli, and Subjective Well-Being Scale (SWBS) developed by Diener et al. The theoretical research model and indirect effects were evaluated using structural equation modeling with partial least squares (PLS-SEM) approach in Smart-PLS3 software.

Results: According to the results, the scales used in the present study were reliable, and their reliability indices were estimated as follows: (Cronbach's alpha: intrinsic motivation $=0.91$, extrinsic motivation $=0.83$, amotivation $=0.77$, energy $=0.90$, subjective well-being $=0.89$; composite reliability: intrinsic motivation $=0.93$, extrinsic motivation $=0.89$, amotivation $=0.87$, energy $=0.92$, subjective well-being $=0.92$ ) and convergent validity (AVE: intrinsic motivation $=0.68$, extrinsic motivation $=0.65$, amotivation $=0.69$, energy $=0.59$, subjective wellbeing=0.69). The discriminant validity was acceptable as well. Also, the general model of the present study had a strong and very good fit according to the goodness of fit index $(\mathrm{GoF}=0.53)$. The results showed that intrinsic motivation $(\beta=0.43, \mathrm{p}<0.001)$ and amotivation $(\beta=-0.19, \mathrm{p}<0.037)$ had significant positive and negative relationships with energy, respectively. The relationship between extrinsic motivation and energy was not significant $(\mathrm{p}>0.05)$. Also, the relationship between energy and subjective well-being was positive and significant $(\beta=0.68, p<0.0001)$. Overall, intrinsic motivation and amotivation predicted $39 \%$ of energy variance, and energy predicted $46 \%$ of mental well-being. Regarding the mediating role of energy, the results showed that energy mediated the relationship between intrinsic motivation and subjective well-being $(\beta=0.29, \mathrm{p}<0.001)$ and the relationship between amotivation and subjective well-being $(\beta=-0.13, \mathrm{p}<0.042)$.

Conclusion: According to the results, intrinsic motivation and amotivation affect nurses' energy in the workplace. Therefore, the researchers of the present study have several practical suggestions for managers to conserve and

\footnotetext{
1. Department of Psychology, Faculty of Educational Sciences and Psychology, Shahid Chamran University of Ahvaz, Ahvaz, Iran

2. Department of Statistics, Faculty of Mathematical Sciences, Ferdowsi University of Mashhad, Mashhad, Iran (Corresponding Author) Tel: +989113413741 Email: hasanalipour@alumni.um.ac.ir

${ }^{3}$. Department of Nursing, Faculty of Nursing and Midwifery, Ahwaz Jundishapur University of Medical Sciences, Ahvaz, Iran
} 
nurture the energy and subjective well-being of their workforce. In this regard, it is suggested that managers increase the internal motivation of employees and reduce their amotivation by increasing participation, increasing the level of authority, the possibility of career advancement, as well as determining more benefits. Creating opportunities for the growth and development of individual skills through empowerment programs, as well as facilitating success by minimizing barriers and reducing pressures and requirements, can also provide the basis for increasing employees' intrinsic motivation. Also, our findings demonstrate that energy is closely related to subjective well-being. Therefore, we recommend that HR practitioners carefully recruit resilient and enthusiastic individuals with high energy levels and an overall positive approach even in adverse and stressful conditions. Moreover, firms should make sincere efforts to promote optimal employee energy levels by formal and informal ways such as: (1) encouraging them to behave enthusiastically, (2) showing persistence even when they encounter negative situations, (3) providing a flexible work environment by allowing short breaks so that employees can relax with co-workers, and (4) holding training and energy management workshops. Here, the real challenge for management is not only to reach an optimal level of employee energy but also to maintain that level. Our study contributes to the subjective well-being literature by bringing attention to the direct and indirect mechanisms that influence the relationship between employee motivation and subjective well-being. We believe that further research in this area will better allow managers to understand how to promote employee happiness and overall well-being. There are few limitations that are needed to be considered while interpreting our research findings. The first limitation of this study is common method variance and mono-method since we utilized self-reported measures for all the study variables, which may inflate or deflate the association between study variables. Future researchers may utilize alternative data sources to reduce mono-method bias, such as manager's appraisals for assessing employee energy level and peer/colleague rating of work motivation in order to verify our proposed model. The second potential limitation is that causality among the study variables cannot be drawn because this study is correlational. Therefore, future studies may try to examine the causation among the study variables by utilizing longitudinal and experimental study designs.

Keywords: Motivation, Energy, Well-being, Nurses

\section{Conflict of Interest: No}

How to Cite: Kaabomeir N, Hasanalipour P, Mousavi SH. The Relationship between Job Motivation Dimensions and Nurses' Subjective Well-being through the Mediating Role of Energy at Workplace. Iran Journal of Nursing . 2021; 34(132):63-76.

Received: 14 Jul 2021

Accepted: 13 Oct 2021 


\title{
رابطه ابعاد انكيزش شغلى با بهزيستى ذهنى برستاران از طريق نقش ميانجى محيط كار
}

\author{
نورى كعبعمير'، يريسا حسنعلىيور '، سيد هاشم موسوى '
}

\begin{abstract}
جكيله
زمينه و هدف: يرستاران در محيطهايى مشغول به كار هستند كه در آن مرگ و زندكى و تأمين سلامتى بيماران از اهم مسائل مىباشد، بنابراين سلامت

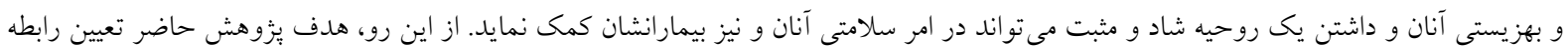

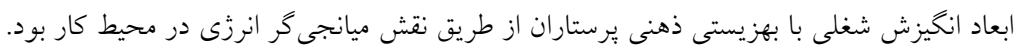

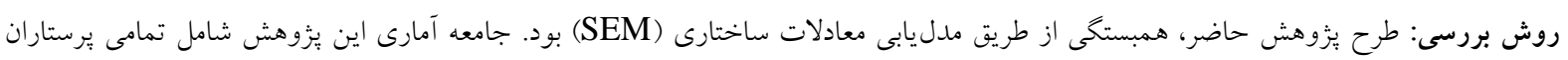

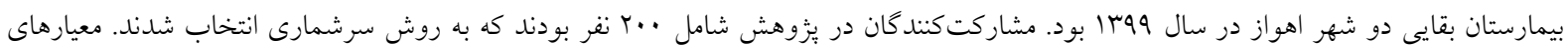

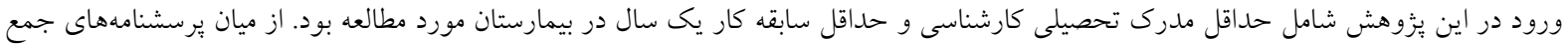

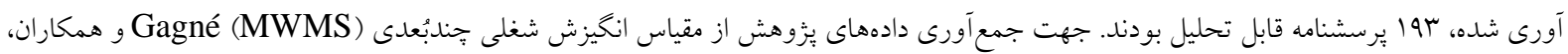

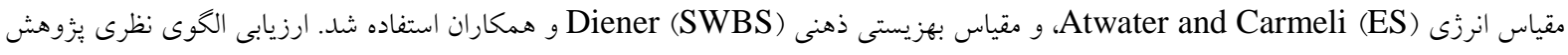

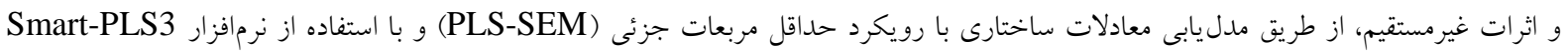

انجام شد. يافتها:

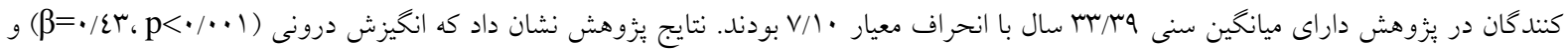

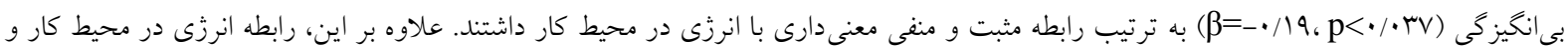

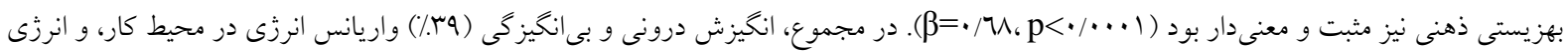



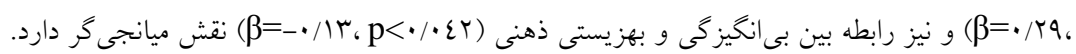

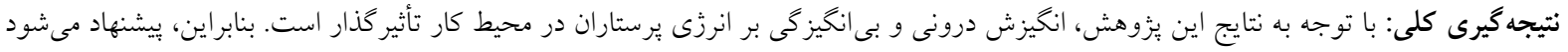

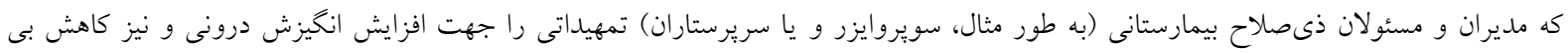

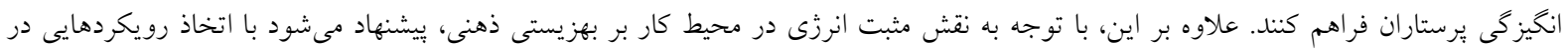

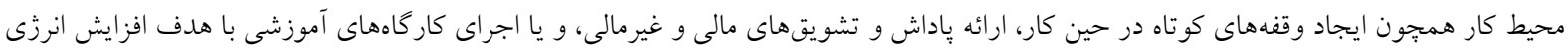

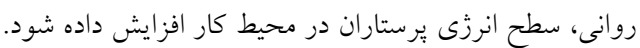
كليد وازهها: انخيزش، انرزى، بهزيستى، برستاران

$$
\text { تاريخ دريخ منافع: ندارد }
$$

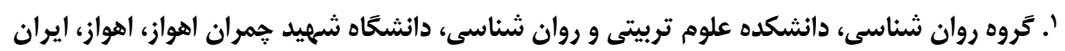


Email: hasanalipour@alumni.um.ac.ir ". تَروه يرستارى، دانشكده يرستارى و مامايیى، دانشكًاه جندى شايور اهواز، اهواز، ايران 
عواملى تمركز كردهاند كه در سطح سازمانى (مانند خودمختارى، پِاداش، آموزش، حمايت شغلى، و و ارزيابى

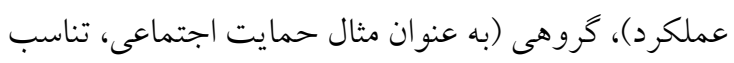



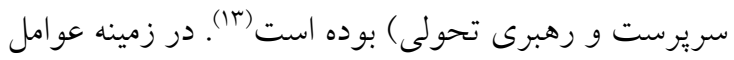

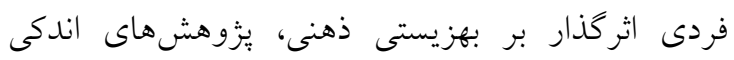

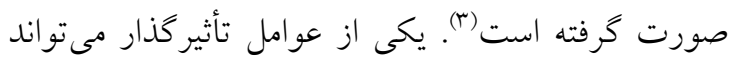
انرزى كاركنان در كار (employee energy at work)


انرزى در حوزه انسانشناسى به يك حالت عاطفى مثبت

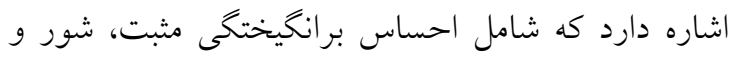
شوق و اشتياق به عمل كردن و توانيى عمل كردن

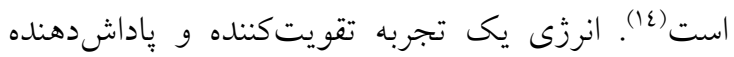

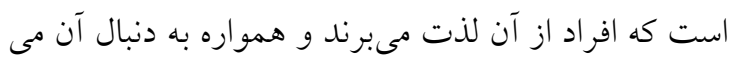
كردند؛ اين تجربه در نشاط و سرزندگى و فقدان خستكى إنى فرد منعكس مى شود (10). سرزندكى به داشتن منابع قابل ورديل

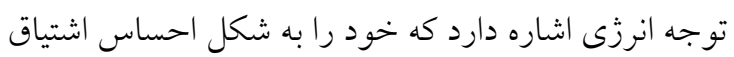
و زنده بودن نشان مىدهد. كاركنانى كه نشاط و سرزند بالايى دارند، همواره احساس هوشيارى، بِ انرزى و و فعال

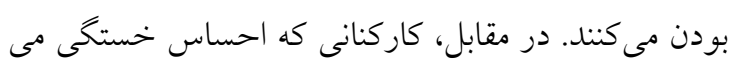

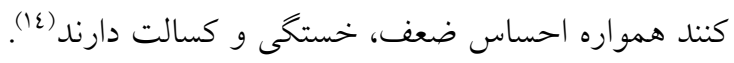
بنابراين، در محيط كار، انرزى همانند (موتور محركهاى") است كه به سازمانها كمك مى كند تا در جهت موفقيت

حركت كنند (17). انرزى كاركنان در محيط شغلى از نظر مفهومى مشابه متغير

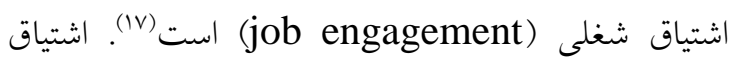
شغلى كه نقش برجستهاى در افزايش اثربخشى فرد و سازمان دارد، به ميزان انززى و دلبستكى به شغل و

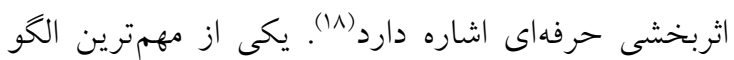

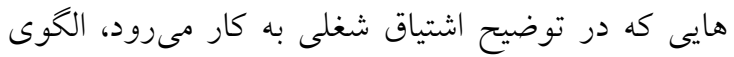
منابع - تقاضاهاى شغلى ( Job Demands-Resources (Model- JD-R است (19). بر اساس اين الكو، منابع شغلى و منابع فردى مهم ترين بيشبينهاى اشتياق شغلى إنى



\section{مقدمه}

سازمانها همواره تلاش مى كنند ضمن دستيابى به بهرهورى و حفظ رقابت مستمر، كاركنانى شاد، سالم و تندرست داشته باشند (1). امروزه سازمانها به طور فزآيندهاى نسبت به اهميت بهزيستى كاركنانشان در تلاش براى دستيابى به

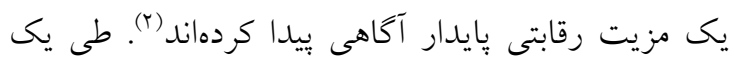
دها كذشته، مفهوم بهزيستى ذهنى ( subjective well

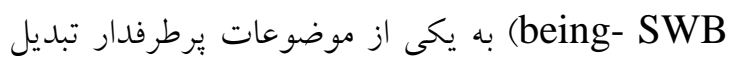

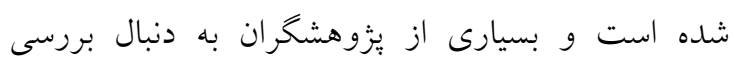

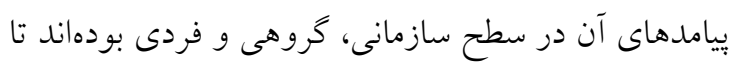

اين مفهوم را در محيط كار مورد مطالعه قرار دهند (r). بهزيستى ذهنى به ارزيابى و درى شخصى افراد از كيفيت

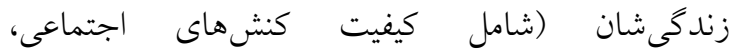
روانشناختى و عاطفى) اشاره دارد (ع). بهزيستى ذهنى داراى سه مؤلفه مجزا و در عين حال مرتبط با يكديخر است: حضور نسبى هيجانات مثبت، فقدان حضور هيجانات منفى

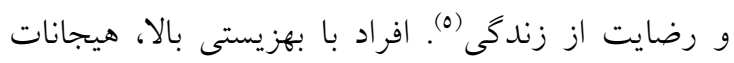
مثبت بيشترى را تجربه مى كنند، از گذشته، آينده خودشان، ديخران، رويدادها و حوادث بيرامونشان ارزيابى مثبتى مئى دارند و آنها را خوشايند توصيف مى كنند. در حالى كه افراد با احساس بهزيستى يايين، موارد مذكور را نامطلوب

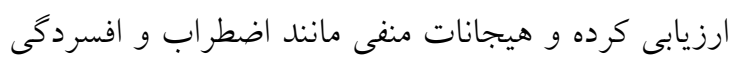
بيشترى را تجربه مى كنند (1). در مجموع، بهزيستى ذهنى ارزيابى مثبت فرد و رضايت كلى او از زندكى خويش است و باعث مىشود افر اد هيجانات مثبت بيشترى را نسبت به هيجانات منفى، تجربه كنند (v). مطالعات نشان داده است كه كاركنان با بهزيستى ذهنى بالاتر شاد، سالم، مولد و روابط بين فردى رضايتبخشى

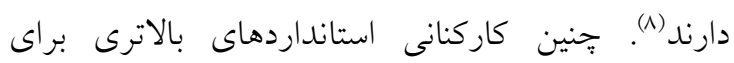
عملكرد شغلى خود تعيين مى كنند (9) و بهرهورى بيشترى دارند(•). علاوه بر اين، بهزيستى ذهنى مىتواند رضايت

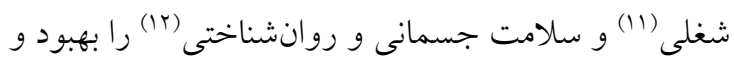

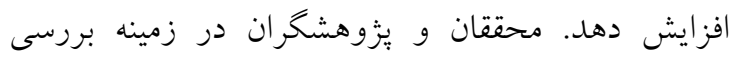

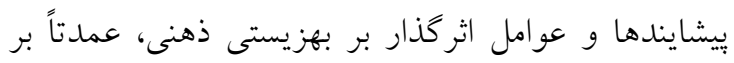


در مقابل، انخيزش بيرونى به مشاركت افراد در رفتارهايى

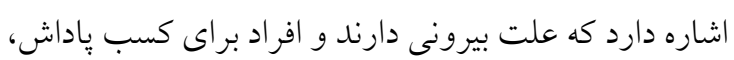

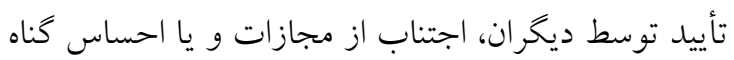

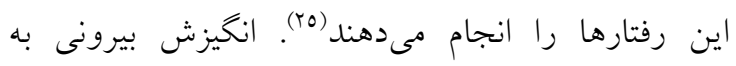
مشاركت در فعاليتى اشاره دارد كه ناشى از فشار و يا كنترل

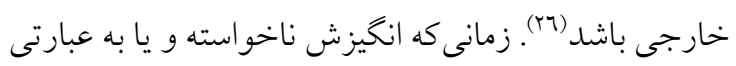


به سمت تنظيم اهداف كوتاممدت سوق مىدهد و اثراتى

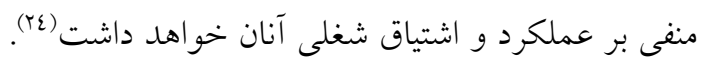

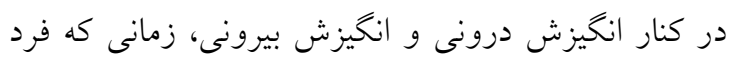
فاقد هركونه انخيزه براى انجام يك فعاليت باشد و دليلى

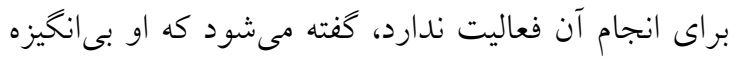

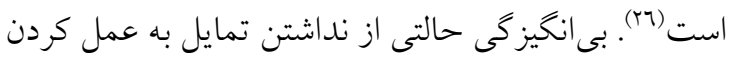
است؛ در زمان بىانخيزه بودن، فرد فاقد قصد و نيت و نيز

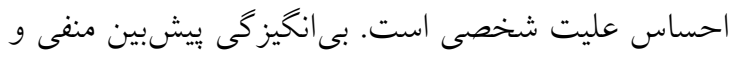

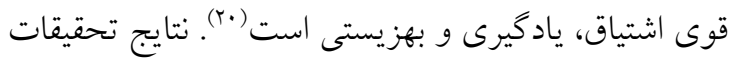

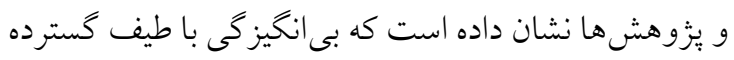



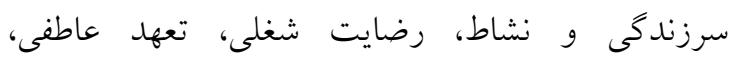


خستخى عاطفى، فرسو دگى شغلى و قصد ترك شغل همر اه است (r) (ra-r) در ميان كاركنان بخش بهداشت و درمان، يرستاران

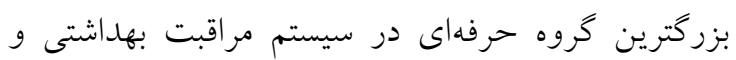
درمانى به حساب مىآيند كه نقش بارزى در سيستم

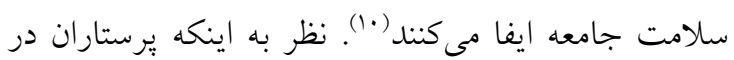

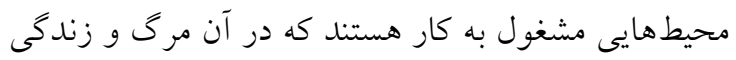

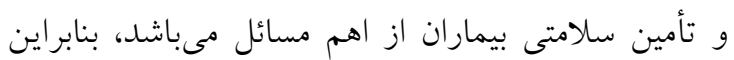

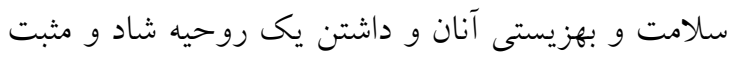

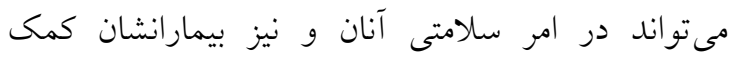

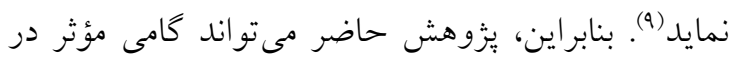

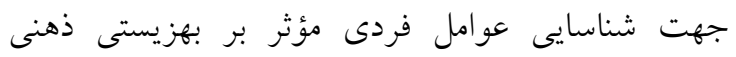

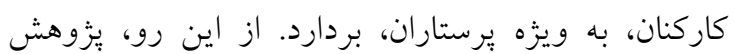

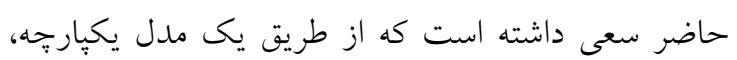

باشند و نيازهاى اساسى روانشناختى افراد را پياسخ مى

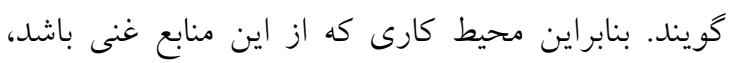

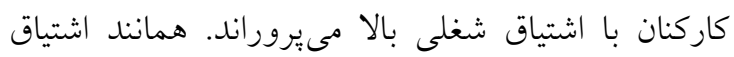
شغلى، براى حفظ و افزايش انرزى كاركنان در محيط كار

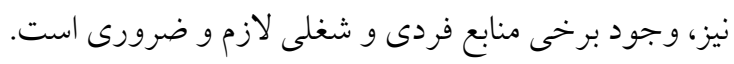

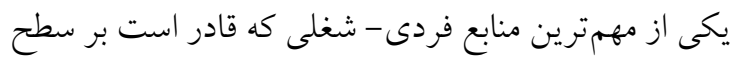

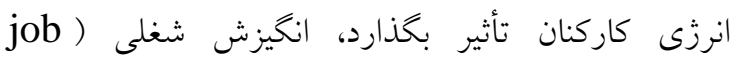


انخيزش شغلى مجموعهاى از نيروهاى اثربخش است كه

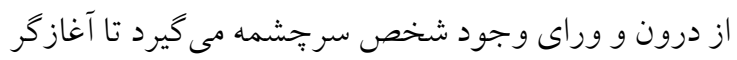



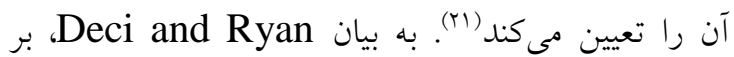

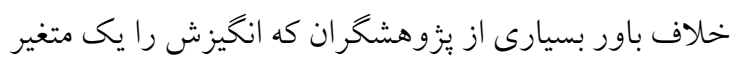



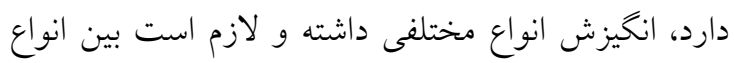

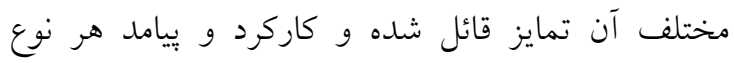

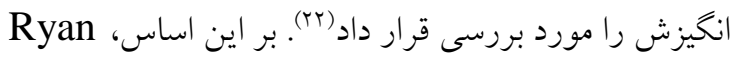
intrinsic ( سه مفهوم انخيزش درونى and Deci extrinsic (motivation (motivation عنوان ابعاد مجزا و مستقل انخيزش شغلى معرفى كرده



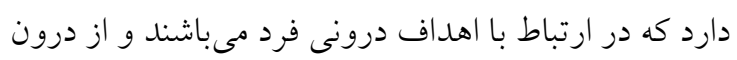

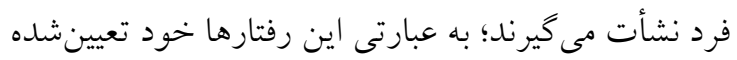

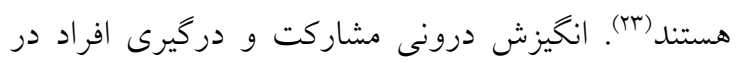

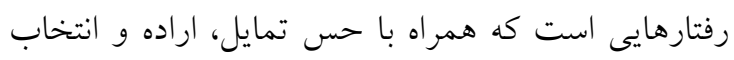

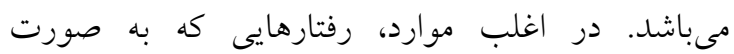
خودمختار تنظيم شدهاند، فرد را از درون بر مى انخيز انند (ع).

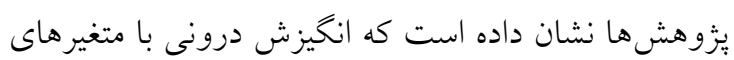
مهم سازمانى و يِيامدهاى فردى در ارتباط است. براى مثال، انخيزش درونى با سطح بالاى تلاش (ro)، سرسختى و تسليم

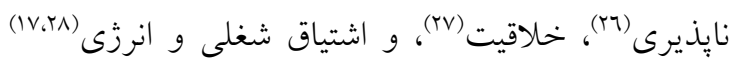

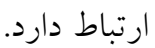


كه شامل جنسيت، سطح تحصيلات، سن و سابقه كار بوده

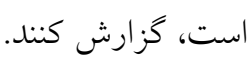

به منظور سنجش متغيرهاى انخيزش درونى، انخيزش

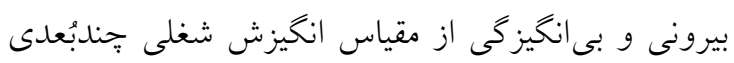
(Multidimensional Work Motivation Scale) Gagné

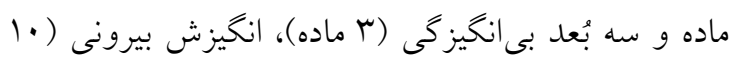

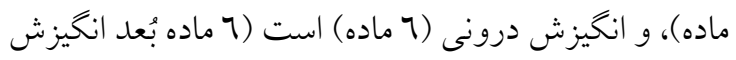

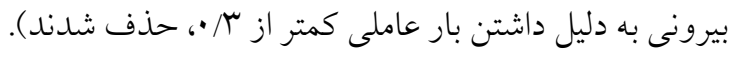

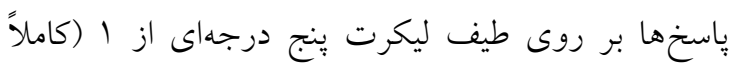

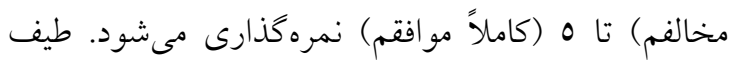





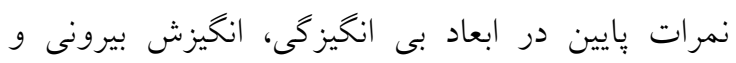



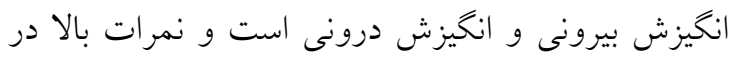

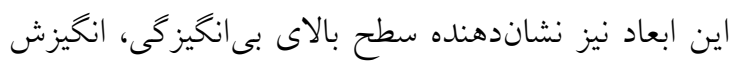

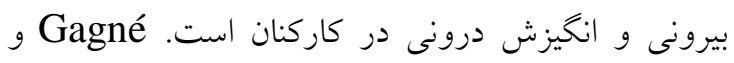

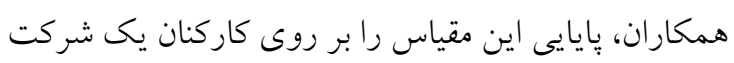

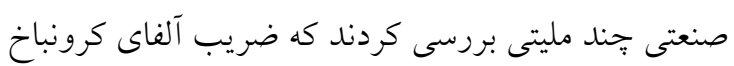

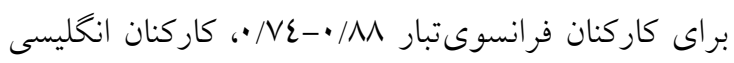

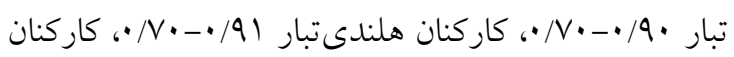

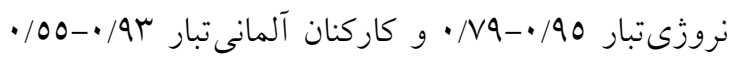

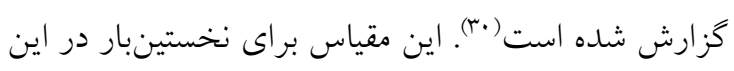
يزوهش، ترجمه و اعتباريابى شده است. روايى صورى و

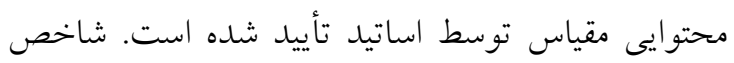

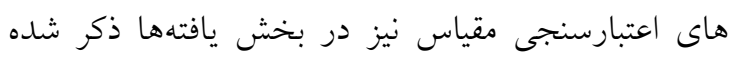

انرزى كاركنان در كار با استفاده از مقياس انرزى Atwater and Carmeli (Energy Scale) سنجش قرار گرفت (rr). در اين مقياس ^م مادهاى از كاركنان خواسته مى شود كه احساس خود را در مورد انرزى مثبتى كه در محيط كار تجربه مى كنند، بر روى طيف ليكرت ئنج

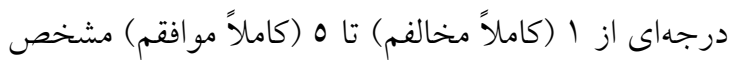

تأثير غيرمستقيم ابعاد انخيزش شغلى شامل انخيزش درونى،

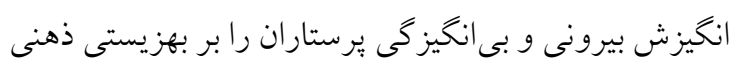
و از طريق نقش ميانجى گر انرزى بررسى كند. ئرسئ.

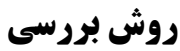

طرح يزوهش حاضر، همبستخى از طريق مدليابى معادلات

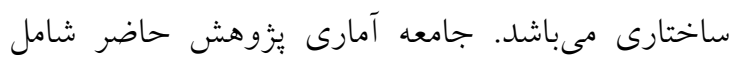

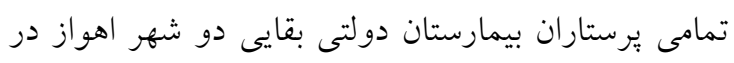

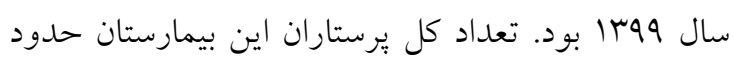

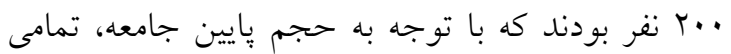
يرستاران به عنوان نمونه يزوهش و به شيوه سرشمارى

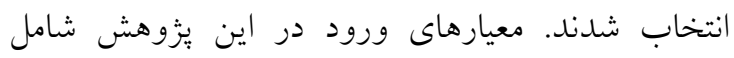

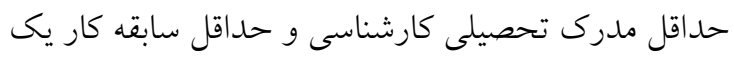

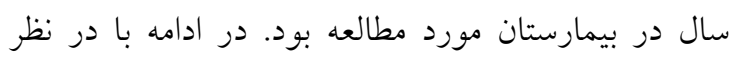

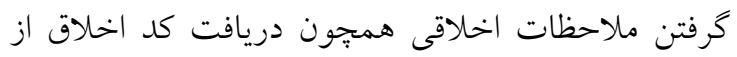

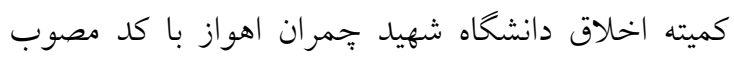
EE/98.24.3.41508/scu.ac.ir مسئولين بيمارستان مورد مطالعه، تضمين محرمانه ماندن

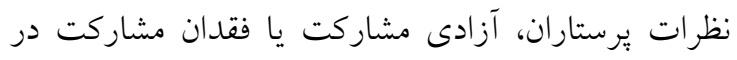

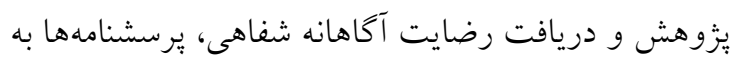

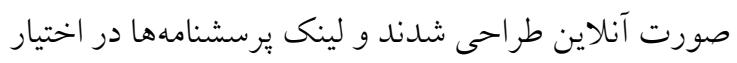

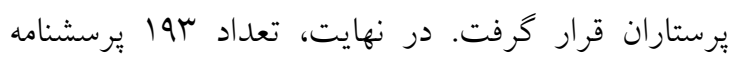
بركشت داده شدند كه اين تعداد حجم نهايى نمونه ران

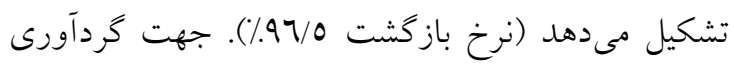

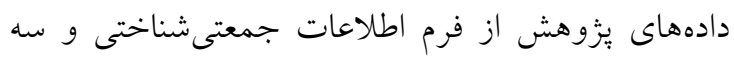
مقياس استاندارد شده استفاده گرديد كه در ادامه توضيح

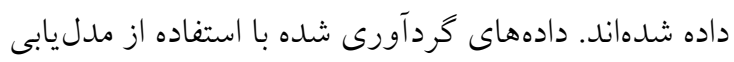

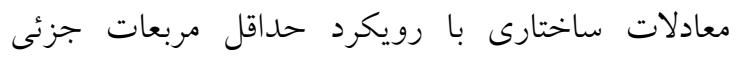
و با كمى نرم افزار Smart-PLS3-SEM)

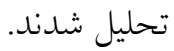

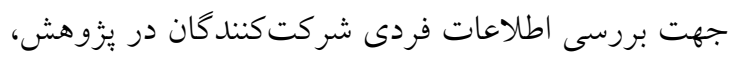
از فرم اطلاعات جمعيتشناختى استفاده شد. در اين فرم از شركت كنندكان خواسته شده بود اطلاعات فردى خود را 
(Reliability- CR



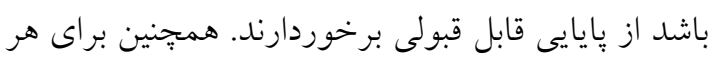

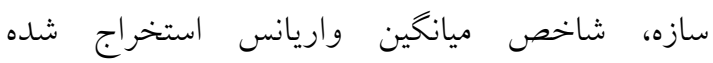
براى (Average Variance Extracted- AVE)

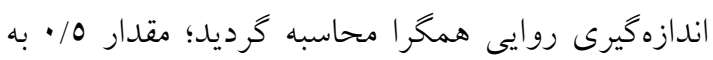
بالا براى نيكويى اين شاخص تعيين شده است. همجنين

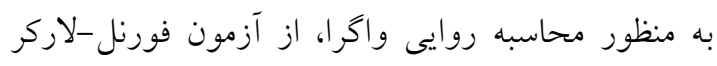

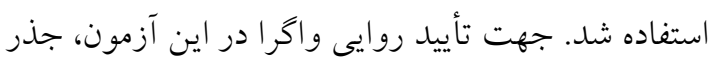

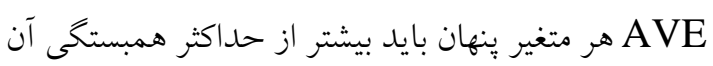

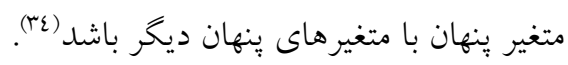

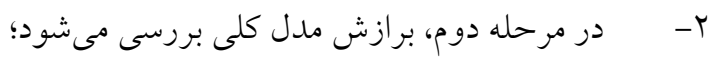

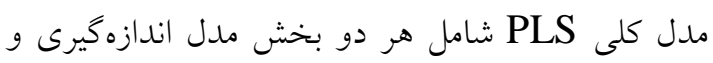

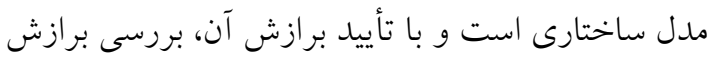

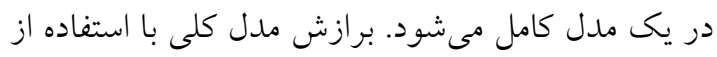
شاخص نيكويى برازش (Goodness of Fit- GoF)

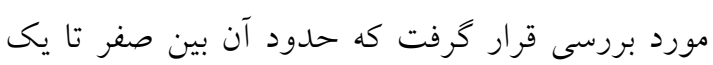


مقادير ضعيف، متوسط و قوى براى اين معيار معرفى شده

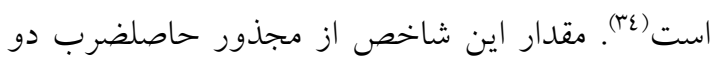

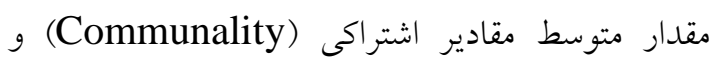
متوسط ضريب تعيين (R2) بدست مى آيد. علاوه بر اين،

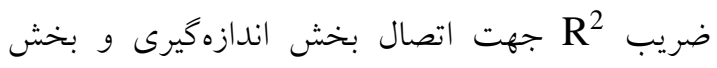
ساختارى مدل سازى معادلات ساختارى نيز به كار مىرود

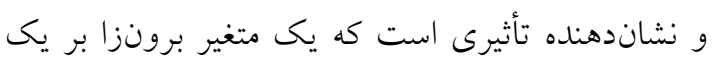

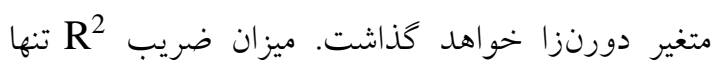
جهت سازههاى درونزا (وابسته) در مدل اندازهيرى دورد صريب

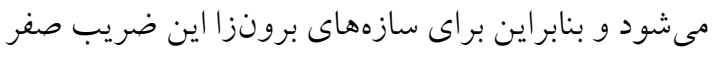

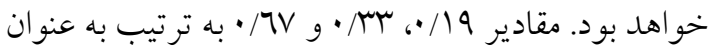

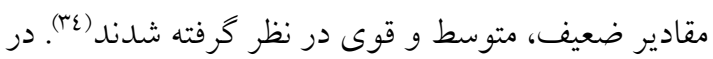

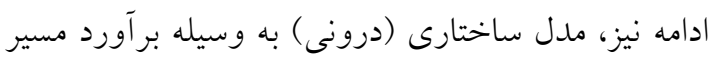
بين متغيرها مورد بررسى قرار مى ميردا.
كنند. طيف نمره كلى انرزى در محيط كار بين ^ تا •ع مى

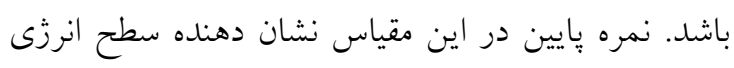

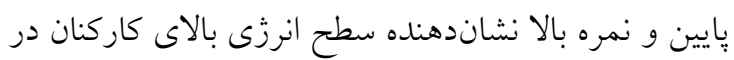

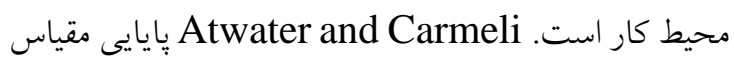

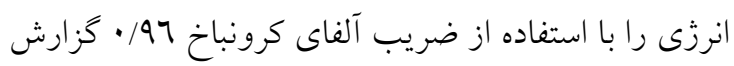

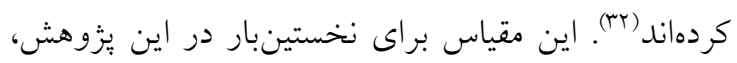

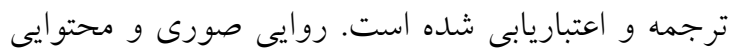

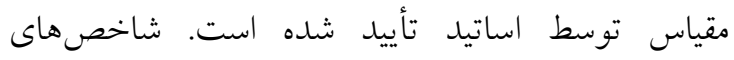
اعتبارسنجى مقياس نيز در بخش يافتهها ذكر شده است.

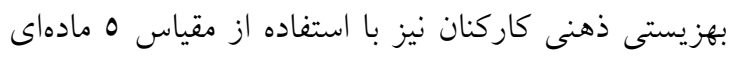
بهزيستى ذهنى (Subjective Well-Being Scale) كه توسط Diener, Emmons, Larsen, and طر احى شده است، مورد سنجش قرار كرفت (rriffin پاسخها در اين مقياس بر روى طيف ليكرت ينج درجهاى

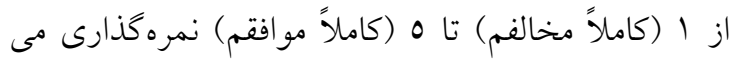

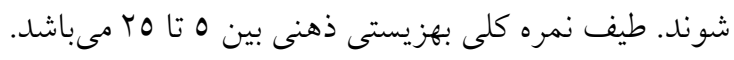

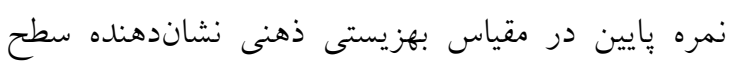

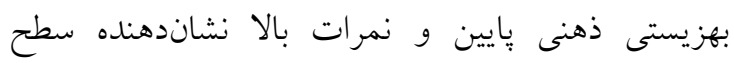
بهزيستى ذهنى بالاى كاركنان است. Diener و همكاران

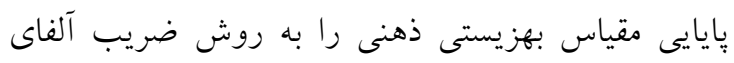

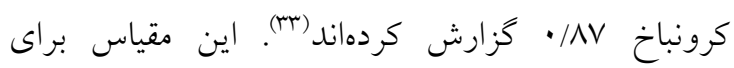
نخستينبار در اين يزووهش، ترجمه و اعتباريابى شده است.

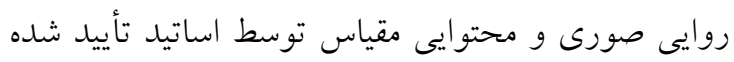
است. شاخصهاى اعتبارسنجى مقياس نيز در بخش يخ يافته

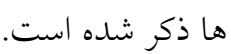
در يُزوهش حاضر، به منظور بررسى اثرات مستقيم و و

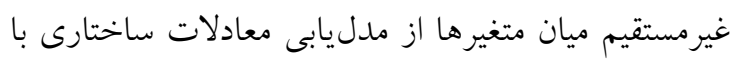

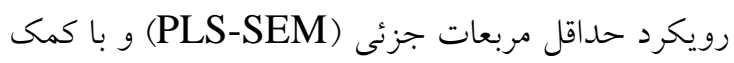

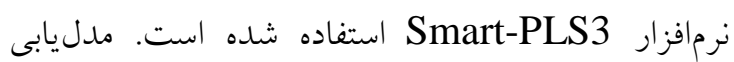
PLS

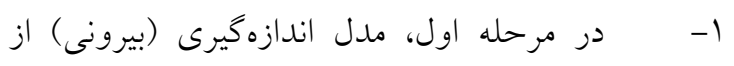

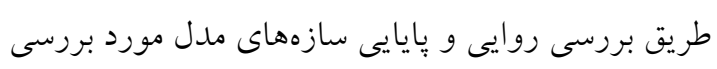

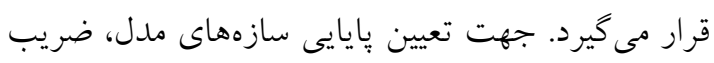
آلفاى كرونباخ و و بِيايى تركيبى ( Composite 
كند كان در يُزوهش داراى ميانخين سنى وس/

يافتهها

انحراف معيار • ل ب/ بودند. جدول شماره ا، نتايج حاصل

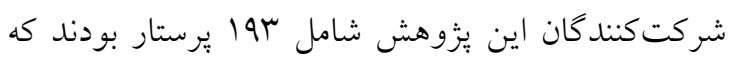
از بررسى پايايى و روايى همخرا، و جدول شماره ب نيز

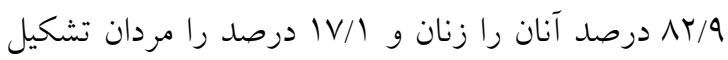



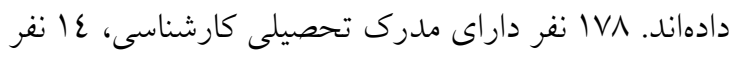
استفاده از نرم افزار Smart-PLS3 نشان مي دورسي دهند.

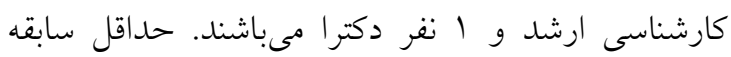

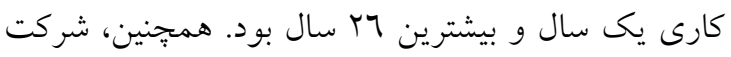

جدول شماره ا: يايايى و روايى مقياسها در يزوهش حاضر

\begin{tabular}{|c|c|c|c|}
\hline AVE & ضريب پايايى تركيبى & ضريب آلفاى كرونباخ & مقياسها \\
\hline$\cdot / 71$ &.$/ 94$ & .191 & انخيزش درونى \\
\hline$\cdot / 70$ & $\cdot / M$ & $\cdot / \Lambda \mu$ & انخيزش بيرونى \\
\hline$\cdot / 79$ & $\cdot / \mathrm{AV}$ & $\cdot / \mathrm{V}$ & بى انخيزگى \\
\hline$\cdot 109$ & $\cdot / 9 r$ & $\cdot / 9$ & انرزى در محيط كار \\
\hline$\cdot / 79$ & $\cdot / 9 T$ & $\cdot / 199$ & بهزيستى ذهنى \\
\hline
\end{tabular}
جدول شماره ؟: ميانكَين، انحر اف معيار، ضرايب همبستكى و روايى افتراقى واتَرا بر اساس معيار فورنل- لاركر

\begin{tabular}{|c|c|c|c|c|c|c|c|c|}
\hline 0 & $\varepsilon$ & $r$ & r & 1 & انحر اف معيار & ميانگين & متغيرها & \\
\hline & & & & $\cdot / \Lambda \mu$ & $O / N r$ & $r \mu / r \varepsilon$ & انخيزش درونى & 1 \\
\hline & & & $\cdot / \Lambda \mid$ & . $10 \mathrm{r}$ & $\mathrm{r} / \mathrm{Tu}$ & $10 / 0 \varepsilon$ & انخيزش بيرونى & r \\
\hline & & ./Ar & $-\cdot / 1$ & $-\cdot / \Gamma V$ & $r / 7 r$ & $0 / V 7$ & بىانخيز گى & r \\
\hline & $\cdot N V$ & $-\cdot / T V$ & $\cdot / \varepsilon$ & $\cdot 109$ & $7 / 77$ & 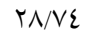 & انرزى در محيط كار & $\varepsilon$ \\
\hline$\cdot / \Lambda r$ & $\cdot / 7 \Lambda$ & $-\cdot / \mu$ & $\cdot / \pi \varepsilon$ & $\cdot 10$ & $0 / 29$ & $1 V / \cdot 9$ & بهز يستى ذهنى & 0 \\
\hline
\end{tabular}

همجنين، نتايج جدول شماره r نشان مىدهد كه جذر AVE

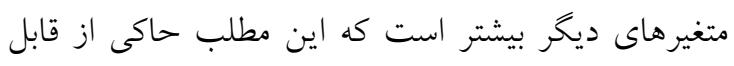
قبول بودن روايى واكراى سازههاى مورد اندازهيرى است. در برازش مدل كلى، مقادير اشتراكى، ضريب تودن نعيين

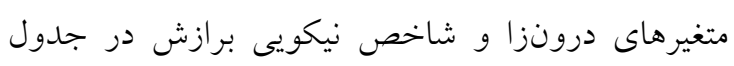

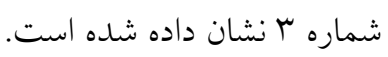

با توجه به نتايج جدول شماره ل، ضريب آلفاى كرونباخ،

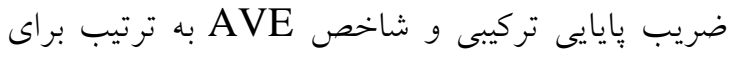

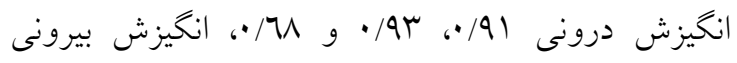



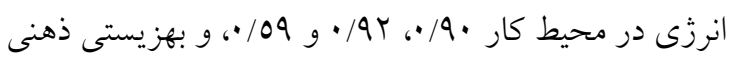

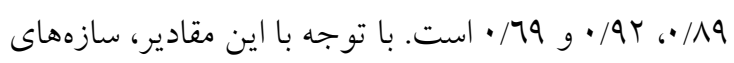

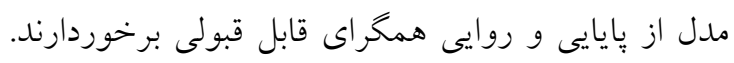

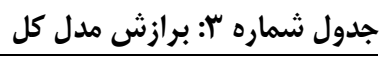

\begin{tabular}{|c|c|c|c|c|c|}
\hline بهزيستى ذهنى & انرزى & بىانگيز گى & انخيزش بيرونى & انگيزش درونى & \\
\hline.$/ 79$ & .109 &.$/ 79$ &.$/ 70$ & $\cdot / 7 /$ & Communality \\
\hline . $/ 27$ & $\cdot \pi q$ & - & - & - & $\mathrm{R}^{2}$ \\
\hline
\end{tabular}

$\mathrm{GoF}=\sqrt{\overline{\text { Communality }} \times \overline{R^{2}}}=\sqrt{0.66 \times 0.43}=0 / 53$ 
نوشته شده بر روى خطوط در نمودار شماره ا، نشاندهنده ضرايب بتا حاصل از معادله رگرسيون ميان متغيرها است كه همان ضرايب مسير مىباشد و اعداد درون هر دايره در


متغيرهاى ينهان درون زاى مدل است. جهت بررسى معنى

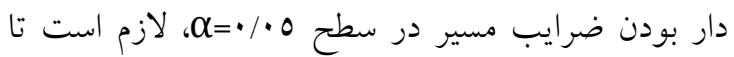
مقدار قدرمطلق t هر مسير از 1/97 بيشتر باشد كه نتايج آن نيز در نمودار شماره Y نشان داده شده است.
با توجه به نتايج جدول شماره آ، مدل كلى يزوهش حاضر


از برازش قوى و بسيار خوبى برخوردار است. همجنين، مقادير R براى متغيرهاى انرزى و بهزيستى ذهنى به تريب

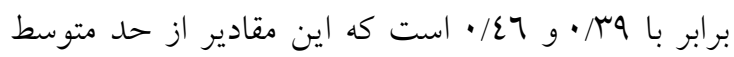
بالاتر هستند و نشاندهنده برازش مطلوب مدل ساختارى است.نتايج حاصل از آزمون مدل يزوهش و مسيرهاى آن در نمودارهاى شماره ا و r نشان داده شده است. مقادير

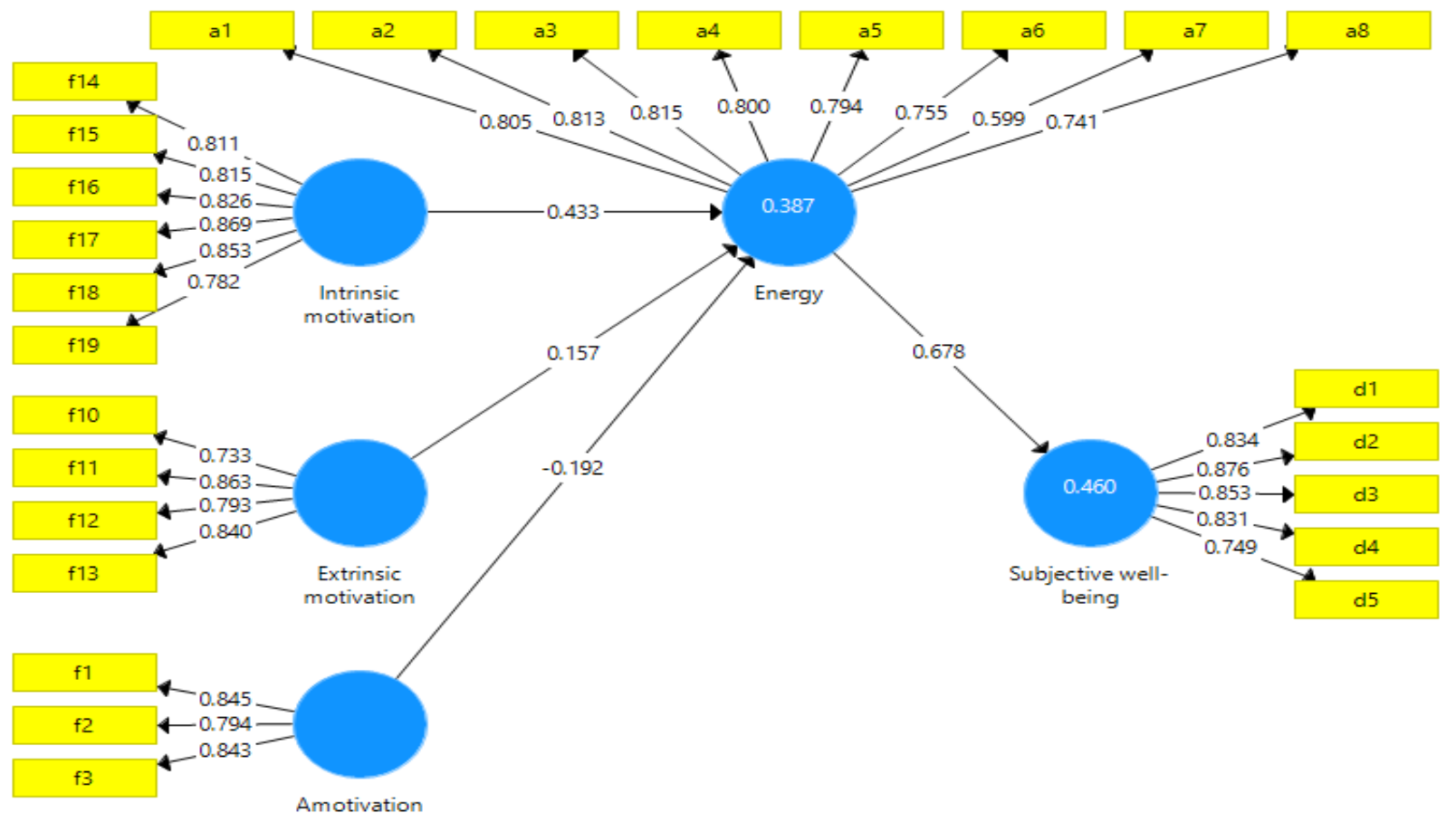

نمودار شماره ا: ضرايب استاندارد مسيرهاى مستقيم بين ابعاد انكَيزش شغلى، انر زيى در محيط كار و بهزيستى ذهنى

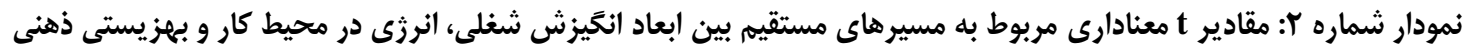

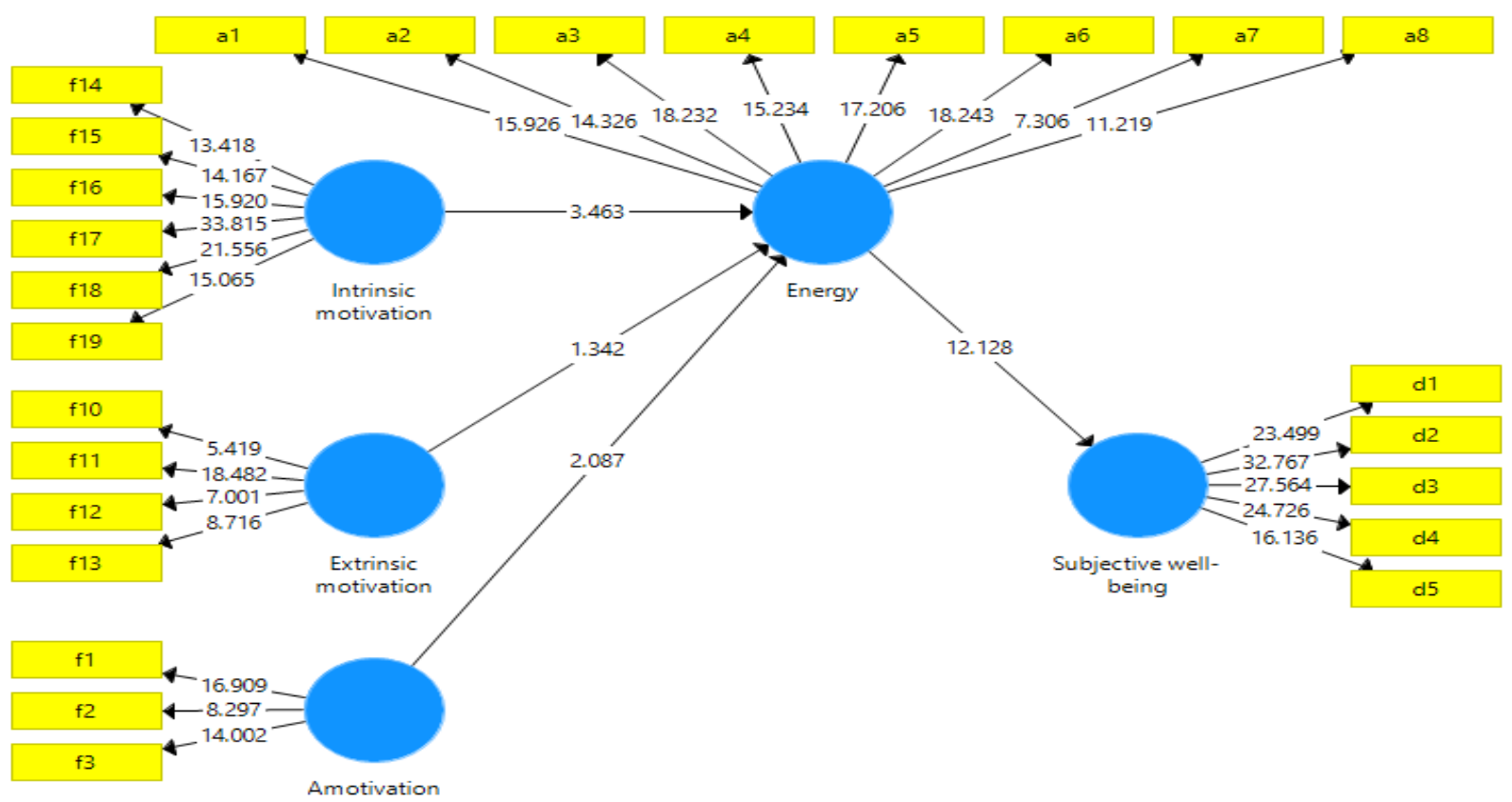




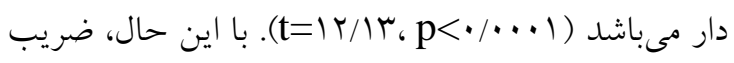

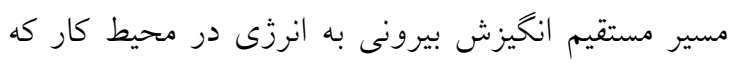

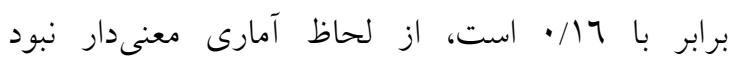
. $(\mathrm{t}=1 / \mu \varepsilon, \mathrm{p}<\cdot / / \Lambda \cdot)$ به منظور بررسى نقش ميانجى انرزى در محيط كار در رابطه

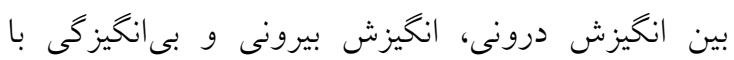

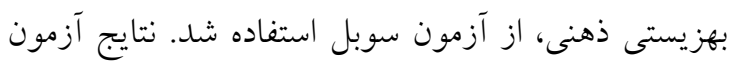
سوبل در جدول شماره ع نشان داده شده است.
با توجه به نتايج ارائه شده در نمودارهاى ا و ؟، ضريب

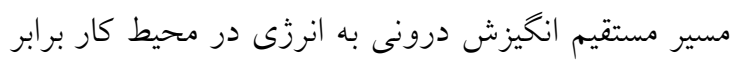

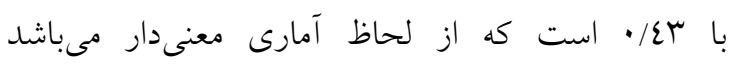

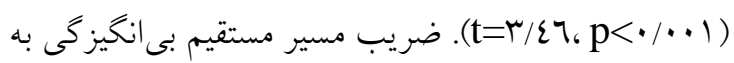
انرزى در محيط كار برابر با 19/، -ـ است كه اين مقدار نيز

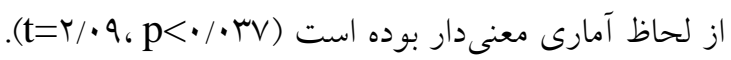
همجنين، ضريب مسير مستقيم بين انرزى در محيط كار و



جدول شماره ع: نتايج بررسى اثرات غيرمستقيم ابعاد انغَيزش شغلى بر بهزيستى ذهنى از طريق انرزى در محيط كار

\begin{tabular}{|c|c|c|c|}
\hline $\mathbf{p}$ & $\mathbf{t}$ & اندازه اثر غيرمستقيم & مسير غيرمستقيم \\
\hline.$/ \cdot 1$ & T/YT &.$/ 79$ & انخيزش درونى † انرزى در محيط كار † بهزيستى ذهنى \\
\hline$\cdot / r \cdot r$ & $1 / \Gamma \Lambda$ &.$/ 11$ & انكيزش بيرونى † انرزى در محيط كار ٪ بهزيستى ذهنى \\
\hline$\cdot / \cdot \varepsilon r$ & $r / \cdot \varepsilon$ & $-\cdot / 14$ & بى انحيزكى ٪ انرزى در محيط كار † بهزيستى ذهنى \\
\hline
\end{tabular}

درونى كاركنان و در نتيجه شور و شوق و انرزى در محيط

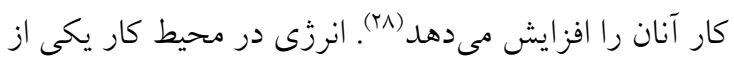

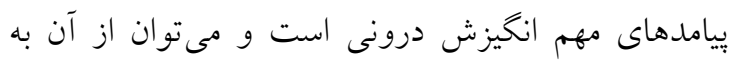
عنوان برانخيختكى مثبت كه شامل الهامبخشى، اشتياق،

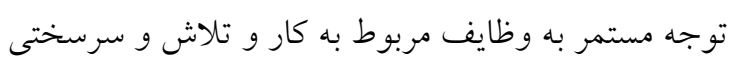

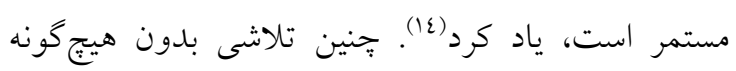

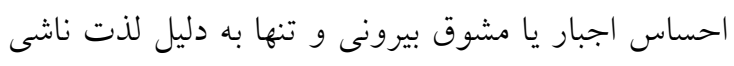
از انجام آن كار رخ مىدهد. انخيزش موتور محركه انسان

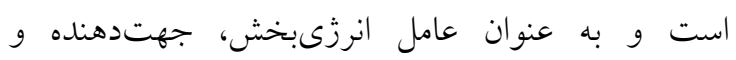
تداومبخش رفتار تعريف شده است (1). كاركنانى كه داراى

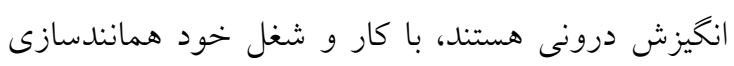

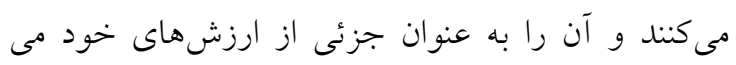
يذّيرند. افراد در جنين شرايطى به اين دليل كه شغلشان

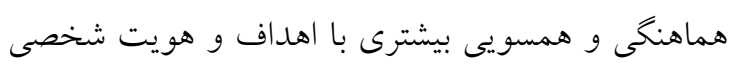

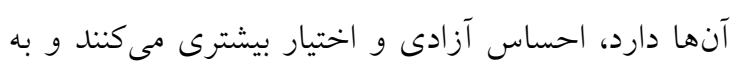

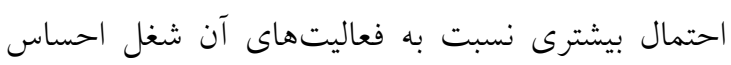

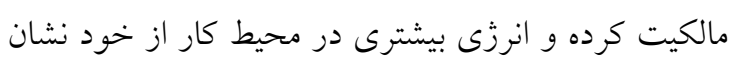
نتايج يزوهش حاضر حاكى از آن بود كه بىانخيز گى رابطه

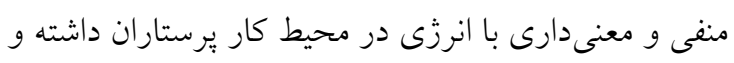

نتايج جدول شماره ع نشان مىدهد كه مسير غيرمستقيم

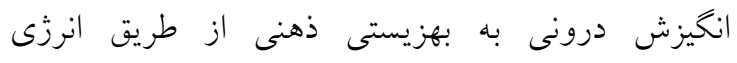

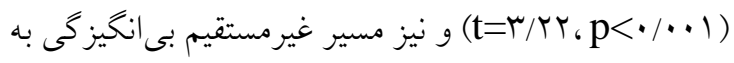

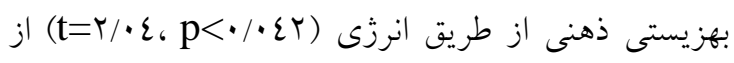



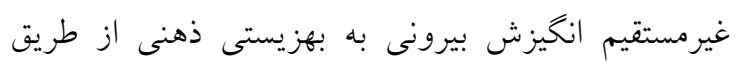

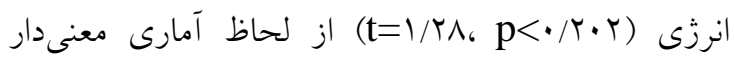

\section{بحث و نتيجه تيرى}

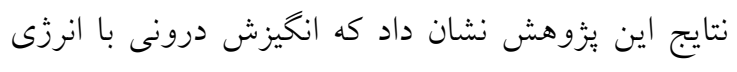

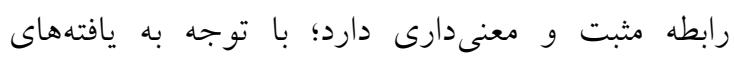

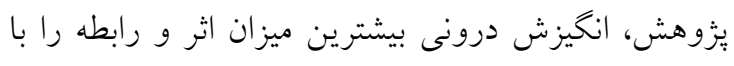

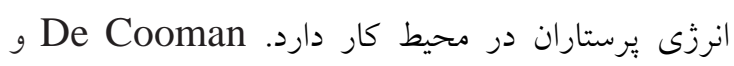

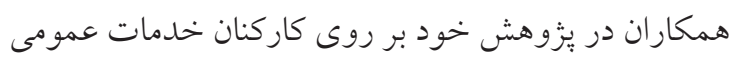

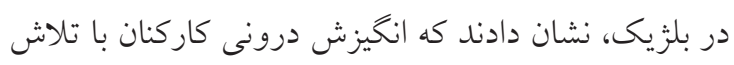

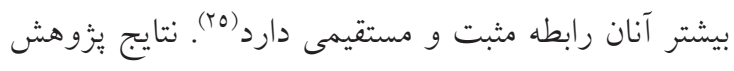
و و همكاران نيز كه يك مطالعه فراتحليل در زمينه بيامدهاى حمايت رهبر از نيازهاى اساسى روانشناختى

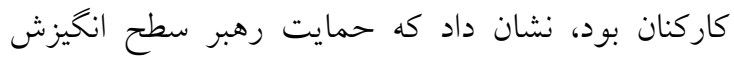


انخيزش درونى و بىانگيزگى معنى دار بوده و از مقدار

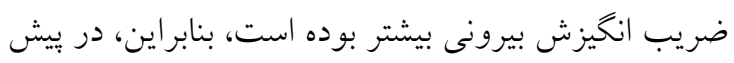

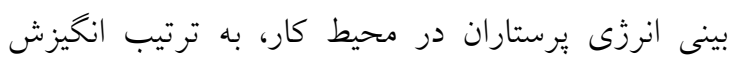

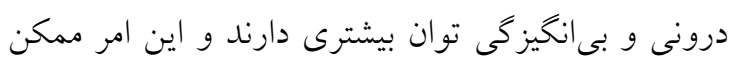

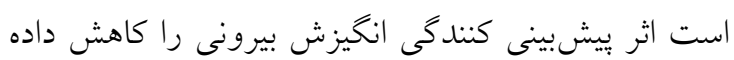



با توجه به نتايج اين بزّوهش، انرزى برستاران در محيط

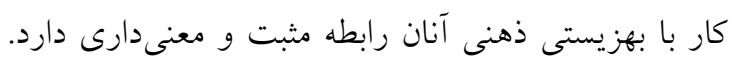
Schiuma قابل توجهى بر ابعاد فيزيكى، شناختى و عاطفى بهزيستى

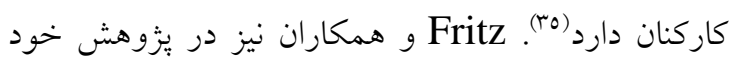
نشان دادند استراتزىهايى كه كاركنان براى افزايش انرزى خود در محيط كار بكار مىبرند، با نشاط و سرزندگى آنان

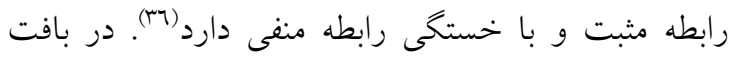

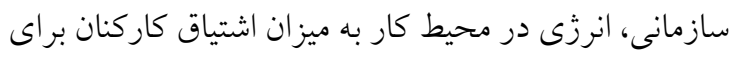
عمل به و تبحر در وظايف محولشده كفته مىشود (rT).

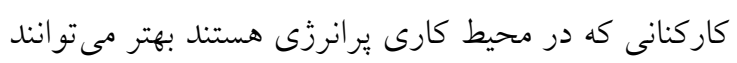

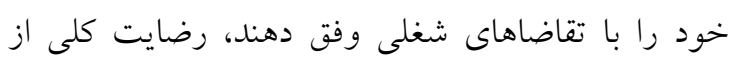

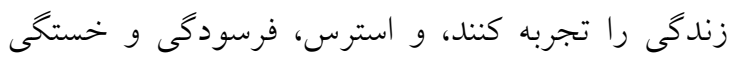

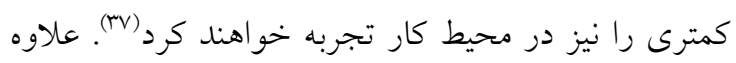

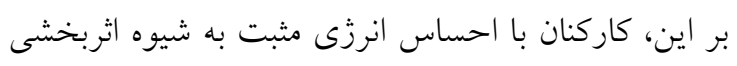

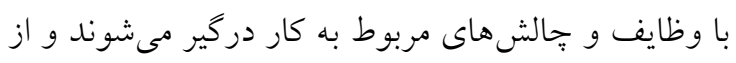

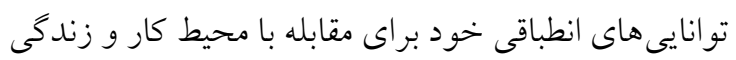

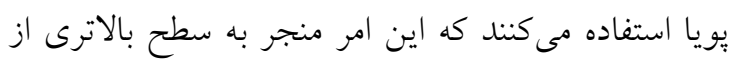

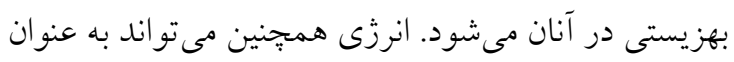


براى بهزيستى ذهنى كاركنان مهم هستند، زيرا فرد را به به

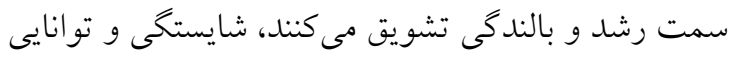
شغلى را افزايش مىدهند و دستيابى به هدف را تسهيل

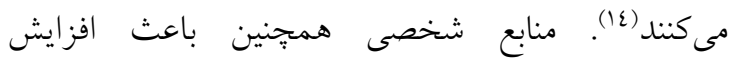

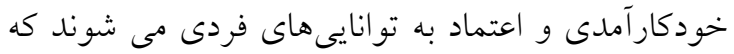

بيشبينى كننده خوبى براى بهزيستى ذهنى هستند.

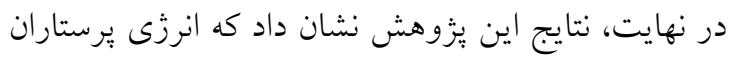



هِ از انخيزش درونى، بيشترين اثر را بر انرزى در محيط

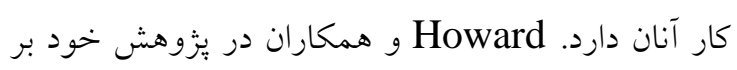
روى كاركنان دولتى و كاركنان شاغل در شركتهاى



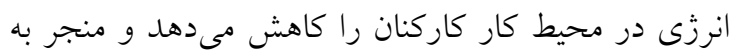

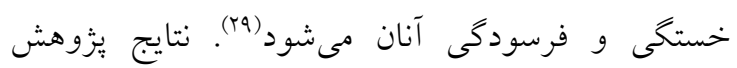
Gagné تلاش، بويايى، سرزندگى و انرزى كاركنان در محيط كار

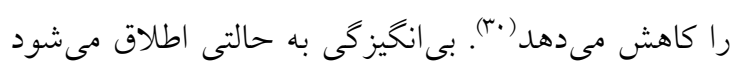

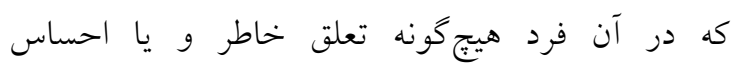
همانندسازى با وظايف كارى خود نداشته و هيج دليلى درد ونه

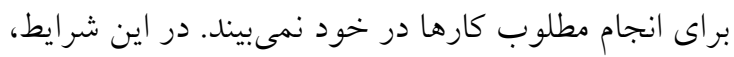
فرد به نوعى حالت انفعال دجار مىشود به كونهاى كه هيج كونه انخيزش درونى و يا بيرونى او را را به انجام كار

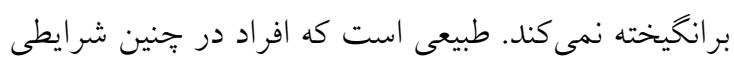

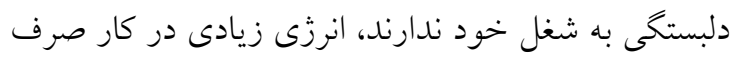

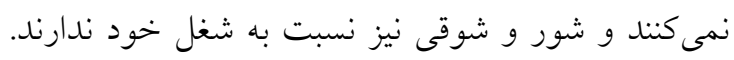

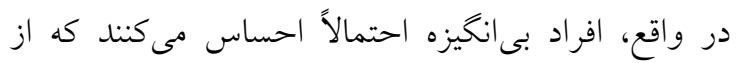

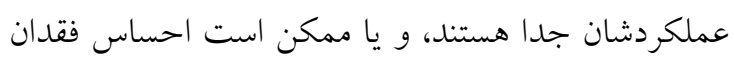

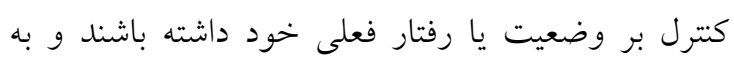
همين دليل وقت و انرزى كمى را صرف اين فعاليتها مى كنند (ra). در ارتباط با رابطه بين انخيزش بيرونى و انرزى در محيط

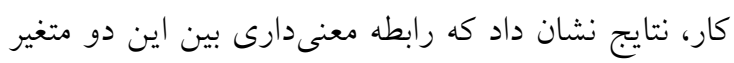

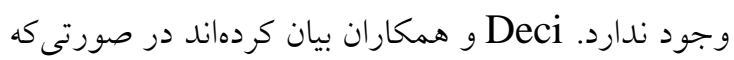

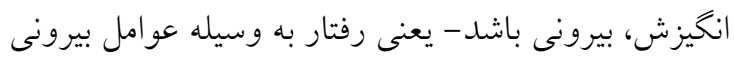

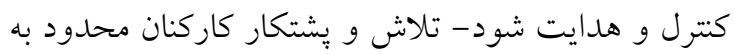
ياداش و يا منافعى خواهد بود كه دريافت مى كنند و در نتيجه، يِيامدهاى مثبت كو تاهمدت انخيزش بيرونى منجر به

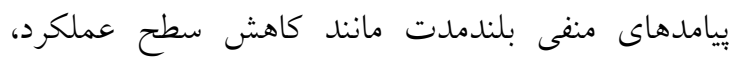

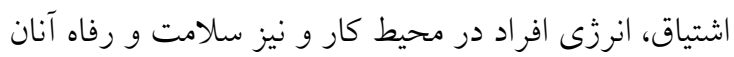

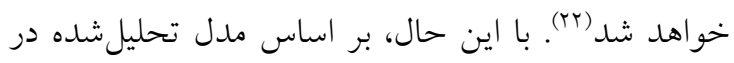



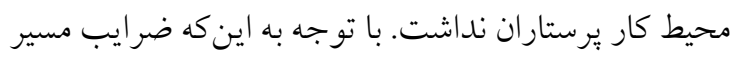


جهت حفظ و يرورش انرزى و بهزيستى ذهنى نيروى كار

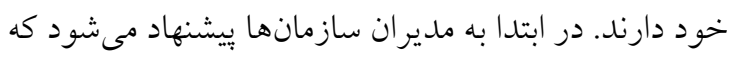



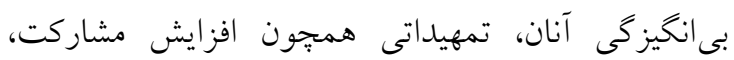
افزايش سطح اختيارات، امكان ارتقاء شغلى و نيز تعيين



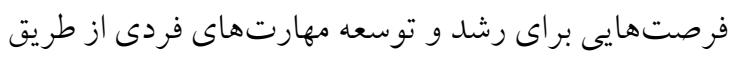

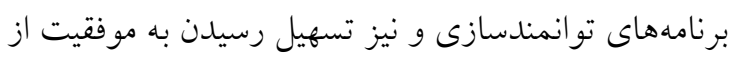

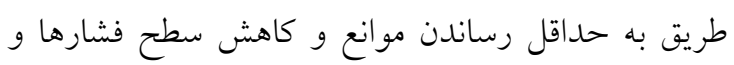

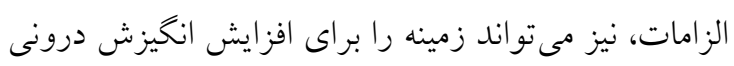

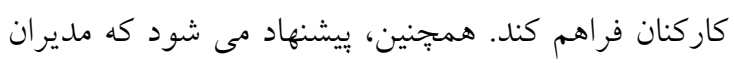

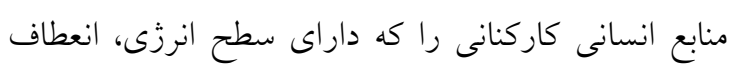

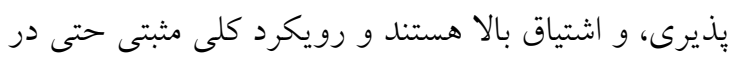
شر ايط نامساعد و استرسز وزا دارند را با دقت استخدام كنند.

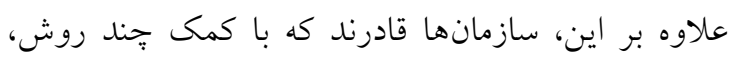

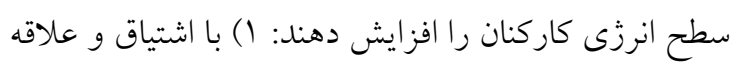

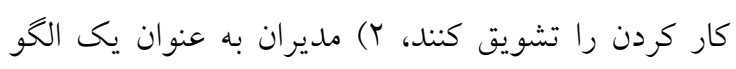

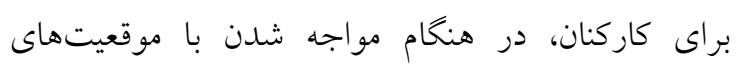
استرسزا و سخت، از خود مقاومت و ايستادكى نشان منان

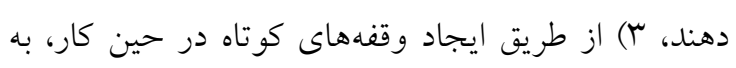

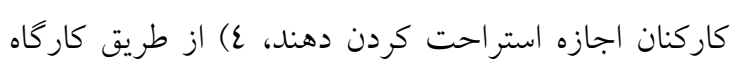

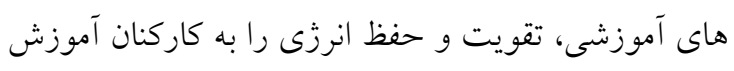

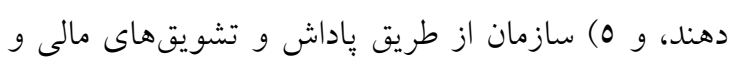

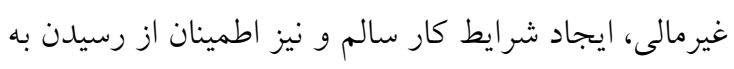

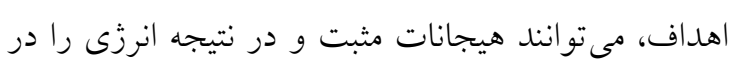
كاركنان ايجاد و تقويت كنند. تعارض منافع. هيج كونه تعارض منافعى بين نويسند وجود ندارد.

\section{تقدير و تشكر}

لازم است در اينجا از حمايتهاى معنوى دانشگاه شهيد جمران اهواز و همجنين، از همكارى تمامى مسئولين و

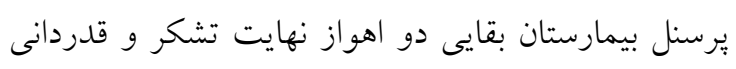

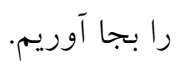

با بهزيستى ذهنى آنان است. در رابطه با اين نتيجه، بثزوهش

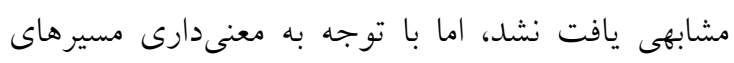

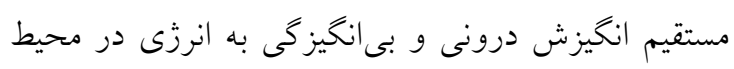

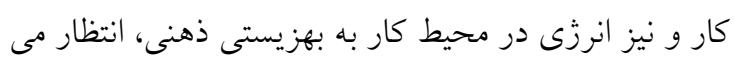
رفت كه جنين نتيجهاى حاصل شود. با توجه به اين نتيجه،





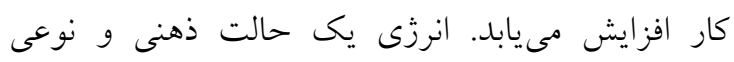

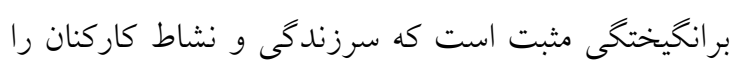

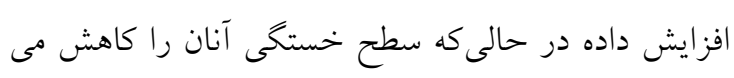

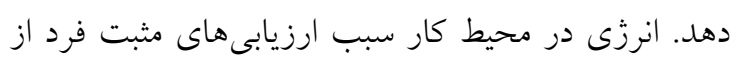
شغل خويش مىشود و به عبارتى، سطح بهزيستى ذهنى وى را ارتقاء مىبخشد. يُزوهش حاضر با محدوديتهايى روبه رو بوده است؛

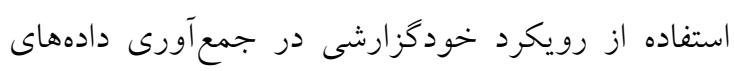
يُزوهش مى تواند محدوديتهايى را به همراه داشته باشد.



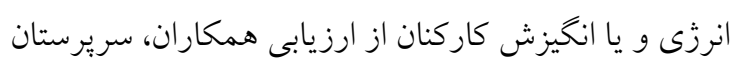

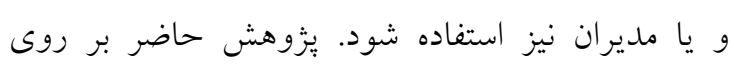

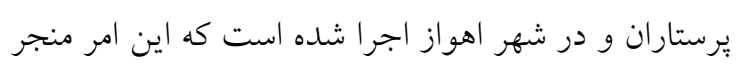

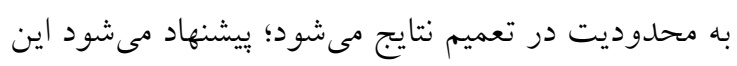



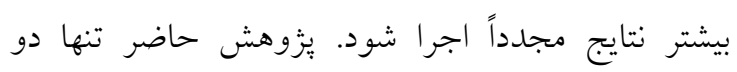

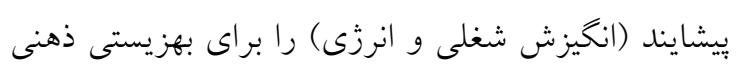

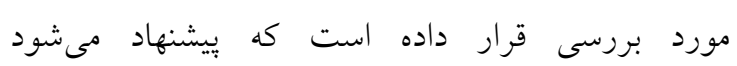



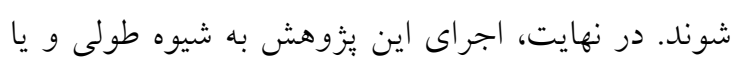

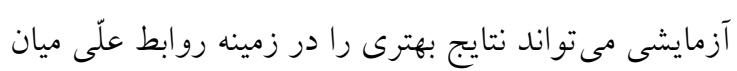
متغيرهاى يزووهش حاضر ارائه دهد.

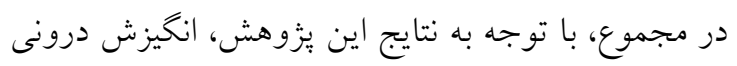

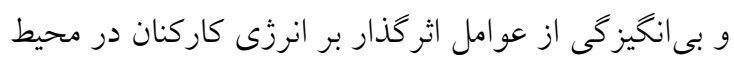

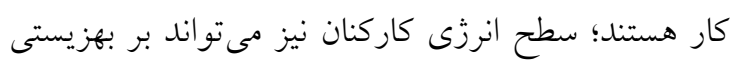

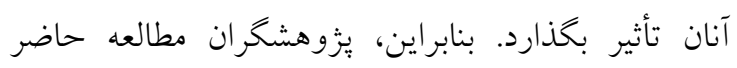
جندين يبشنهاد كاربردى براى مديران و دست اندركاران 


\section{References}

1. Calvard TS, Sang KJ. Complementing psychological approaches to employee well-being with a socio-structural perspective on violence in the workplace: An alternative research agenda. Int $J$ Human Resource Manag. 2017;28(16):2256-74.

2. Nielsen K, Nielsen MB, Ogbonnaya C, Känsälä M, Saari E, Isaksson K. Workplace resources to improve both employee well-being and performance: A systematic review and meta-analysis. Work \& Stress. 2017;31(2):101-20.

3. Diener E, Ryan K. Subjective well-being: A general overview. South African J Psychol. 2009;39(4):391-406.

4. Page KM, Vella-Brodrick DA. The 'what', 'why' and 'how'of employee well-being: A new model. Social indicators research. 2009;90(3):441-58.

5. Peyvastegar M. Relationship between creativity and subjective well-being. International Journal of Behavioral Sciences. 2010;4(3):207-13. [Persian]

6. Luhmann M, Intelisano S. Hedonic adaptation and the set point for subjective well-being. In E, Handbook of well-being. Salt Lake City, UT: DEF Publishers. 2018.

7. Ryff CD. Psychological well-being revisited: Advances in the science and practice of eudaimonia. Psychotherapy and psychosomatics. 2014;83(1):10-28.

8. Ghosh A, Deb A. Positive psychology progress in India: Accomplishments and pathways ahead. Psychological Studies. 2016;61(3):113-25.

9. Bakker AB, Oerlemans W. Subjective well-being in organizations. The Oxford handbook of positive organizational scholarship. 2011;49:178-89.

10. Yosefi M. Comparison of happiness, psycholigy well-being and job perfectionism among women nurses of different sections of haspitals in isfahan at 2014. Avicenna Journal of Nursing and Midwifery Care. 2015;23(2):52-62. [Persian]

11. Berglund V, Johansson Sevä I, Strandh M. Subjective well-being and job satisfaction among selfemployed and regular employees: does personality matter differently? J Small Busin Entrepreneurship. 2016;28(1):55-73.

12. Robertson IT, Birch AJ, Cooper CL. Job and work attitudes, engagement and employee performance: Where does psychological well-being fit in? Leadership \& Organization Development Journal. 2012;33(3): 224-32.

13. Butt TH, Abid G, Arya B, Farooqi S. Employee energy and subjective well-being: a moderated mediation model. The Service Industries Journal. 2020;40(1-2):133-57.

14. Quinn RW, Dutton JE. Coordination as energy-in-conversation. Acad Manag Review. 2005;30(1):36-57.

15. Vasconcelos AF. Positive Organizational Scholarship Concept: an Overview and Future Studies1. REAd. Revista Eletrônica de Administração (Porto Alegre). 2018:85-128.

16. Russo M, Shteigman A, Carmeli A. Workplace and family support and work-life balance: Implications for individual psychological availability and energy at work. The Journal of Positive Psychology. 2016;11(2):173-88.

17. Menges JI, Tussing DV, Wihler A, Grant AM. When job performance is all relative: How family motivation energizes effort and compensates for intrinsic motivation. Acad Manag J. 2017;60(2):695-719.

18. Morales-Rodríguez FM, Pérez-Mármol JM, Brown T. Education burnout and engagement in occupational therapy undergraduate students and its associated factors. Frontiers in psychology. 2019;10:2889.

19. Bakker AB. An evidence-based model of work engagement. Current directions in psychological science. 2011;20(4):265-9.

20. Ryan RM, Deci EL. Intrinsic and extrinsic motivation from a self-determination theory perspective: Definitions, theory, practices, and future directions. Contemporary Educational Psychology. 2020;61:101860.

21. Ramírez García I, Del Cerro Ramón S, Fornells Herrera A. The role of work motivation based on values in employee's retention in the $21^{\text {st }}$ century. Management Studies. 2019; 7(2): 149-56. 
22. Van den Broeck A, Ferris DL, Chang CH, Rosen CC. A review of self-determination theory's basic psychological needs at work. Journal of Management. 2016;42(5):1195-229.

23. Hagger MS, Hardcastle SJ, Chater A, Mallett C, Pal S, Chatzisarantis NL. Autonomous and controlled motivational regulations for multiple health-related behaviors: between-and withinparticipants analyses. Health Psychology and Behavioral Medicine: An Open Access Journal. 2014;2(1):565-601.

24. Deci EL, Olafsen AH, Ryan RM. Self-determination theory in work organizations: The state of a science. Annual review of organizational psychology and organizational behavior. 2017;4:19-43.

25. De Cooman R, Stynen D, Van den Broeck A, Sels L, De Witte H. How job characteristics relate to need satisfaction and autonomous motivation: Implications for work effort. $J$ Appl Social Psychol. 2013;43(6):1342-52.

26. Deci EL, Ryan RM. Facilitating optimal motivation and psychological well-being across life's domains. Canadian psychology/Psychologie canadienne. 2008;49(1):14-23.

27. Kark R, Van Dijk D, Vashdi DR. Motivated or demotivated to be creative: The role of selfregulatory focus in transformational and transactional leadership processes. Applied Psychology. 2018;67(1):186-224.

28. Slemp GR, Kern ML, Patrick KJ, Ryan RM. Leader autonomy support in the workplace: A metaanalytic review. Motivation and emotion. 2018;42(5):706-24.

29. Howard J, Gagné M, Morin AJ, Van den Broeck A. Motivation profiles at work: A selfdetermination theory approach. $J$ Vocation Behav. 2016;95:74-89.

30. Gagné M, Forest J, Vansteenkiste M, Crevier-Braud L, Van den Broeck A, Aspeli AK, Bellerose J, Benabou C, Chemolli E, Güntert ST, Halvari H. The Multidimensional Work Motivation Scale: Validation evidence in seven languages and nine countries. Europ J Work Organiz Psychol. 2015;24(2):178-96.

31. Tremblay MA, Blanchard CM, Taylor S, Pelletier LG, Villeneuve M. Work Extrinsic and Intrinsic Motivation Scale: Its value for organizational psychology research. Canadian Journal of Behavioural Science/Revue canadienne des sciences du comportement. 2009;41(4):213-26.

32. Atwater L, Carmeli A. Leader-member exchange, feelings of energy, and involvement in creative work. The Leadership Quarterly. 2009;20(3):264-75.

33. Yun YH, Rhee YE, Kang E, Sim JA. The Satisfaction with Life Scale and the Subjective WellBeing Inventory in the general Korean population: psychometric properties and normative data. Int J Environm Res Public Health. 2019;16(9):1538.

34. Shakuna KS, Mohamad N, Ali AB. Modelling professional performance of teachers' scales in libyan schools. Int J Manag appl Res. 2016;3(3):120-9.

35. Schuiuma G, Mason S, Kennerley M. Assessing energy within organizations. Measuring Business Excellence. 2007;11(3):69-78.

36. Fritz C, Lam CF, Spreitzer GM. It's the little things that matter: An examination of knowledge workers' energy management. The Academy of Management Perspectives. 2011; 25(3): 28-39.

37. Peñalver J, Salanova M, Martínez IM, Schaufeli WB. Happy-productive groups: How positive affect links to performance through social resources. Journal Positive Psychol. 2019;14(3):377-92. 